\title{
INTERACTION OF SOIL-CEMENT PILE SUPPORTING STRUCTURES WITH THE BODY OF A LANDSLIDE
}

\footnotetext{
${ }^{1 *}$ Dep. «Bridges and Tunnels», Dnipropetrovsk National University of Railway Transport named after Academician V. Lazaryan, Lazaryan St., 2, Dnipro, Ukraine, 49010, tel. +38 (093) 44236 63, e-mail dola1992@i.ua, ORCID 0000-0001-6805-6703

$2^{*}$ Dep. «Bridges and Tunnels», Dnipropetrovsk National University of Railway Transport named after Academician V. Lazaryan, Lazaryan St., 2, Dnipro, Ukraine, 49010, tel. +38 (050) 70850 69, e-mail petrenko1937@mail.ru, ORCID 0000-0002-5902-6155

${ }^{3 *}$ Dep. «Bridges and Tunnels», Dnipropetrovsk National University of Railway Transport named after Academician V. Lazaryan, Lazaryan St., 2, Dnipro, Ukraine, 49010, tel. +38 (096) 92538 28, e-mail tutkin@mail.ru, ORCID 0000-0003-4921-4758
}

Purpose. Analysis and comparison of the landslide slope finite element model calculation results of the appliance of soil-cement piles, depending on the variation of the retaining structure rigidity, makes it possible to evaluate the effectiveness of their application and the cooperative work of piles with the displacement body. It also makes it possible to make a conclusion about the advantages of using this anti-landslide protection method of the slope. Methodology. Analysis of geomorphological data obtained from the results of laboratory studies of soils on the slope section is considered. Creation of a three-dimensional finite-element slope model according to the constructed sections and depths of the soil layers. Calculation of the nonlinear problem of finite element modeling of the slope with applying of soil-cement piles of various rigidity. Findings. The obtained results of calculating the finite element model of the landslide slope, and the analysis of the stress-strain state of the construction with soil-cement piles has been carried out. Originality. Despite the widespread of using soil-cement piles as enclosing structures for the construction of foundation pits and reinforcement of foundations of emergency structures, special attention should be paid to the study of the expediency of using soil-cement retaining pile structures on landslide areas. Practical value. It is known that soil-cement retaining piles are expediently in use as a protective element, which interacts quite well with the ground environment due to its structure of the initial material. Using of modern computer programs of finite element modeling makes it possible to calculate the efficiency of the use of soil-cement piles and to determine the parameters of the necessary retaining structure according to the given geological structure of the slope, and also, depending on its shape and the physical characteristics of the soils, to compare the performance of different protective landslide structures types.

Key words: soil-cement retaining pile; shear; anti-landslide retaining structure; landslide slopes

\section{Introduction}

Engineering and geological conditions for the construction of multi-stored residential complexes are not always sufficiently favorable in the conditions of Dnipro city development. In some cases, such construction requires additional engineering surveys and calculations. Especially when it comes to the development of engineering and geological protection landslide area of the slope, where it has been planned to construct the building. In this case, to prevent the threat of landslides, such measures are necessary and mandatory. In other words, the designers are faced with the task of developing retaining structures, restraining the slope, possibly moving and sliding which can lead to a catastrophe [1-2].

Since the prerequisites of landslides can sometimes be absent or hidden at first sight, when everything seems to be in order and there is no danger of a shift next to the construction site, but subsequently under certain circumstances there are changes that contribute to the development of certain conditions, the effect of which subsequently can lead to worse consequences than in the beginning.

In fact, this problem is even more complex. Disregarding the prediction of this situation in advance - it is possible to make a mistake in the cal- 
culation. Because of sudden groundwater level rising and it must always be taken into account, the physical characteristics of some soils can be changed, and it may be threat by a large-scale catastrophe. Especially such a threat arises in the spring during the snow melting, when the water drainage system and utilities require increased attention and supervision by the municipal service of the city. [4, 5, 7].

Geographically, the right bank of the Dnipro is located on 4 hills, which are divided by 15 ravines and more than 40 ravines that have landslide areas. The total length of the network of ravines is more than $120 \mathrm{~km}$ and covers an area of about 5 thousand hectares. Under such conditions it is necessary to constantly monitor the state of engineering networks in the city, and to respond in a timely manner to any changes. $[6,12,14]$

The object of the study is the territory of the Krasnopovstanskaya ravine on Zhukovsky Street in the area of houses No. $16-24$ in the city of Dnipro. On the adjacent territory, where the construction of a multifunctional complex of civil and residential purposes is located with landscaping, previously landslide processes took place. For a more complete understanding of the features of the area, the survey materials have been collected and studied, which have been conducted within the study area.

The area, which is considered in engineeringgeological terms, has been studied quite well. Since 1980 to the present time, GP «DniproDIITS» (State Institute of Engineering and Technical Surveys), together with other survey and design and survey organizations conducted engineering and geological surveys for the design and construction of various public facilities.

Engineering and geological surveys included such types of works as well drilling, trench hole trenching, ground pressure testing, experimental filtration, laboratory studies of soils and groundwa- ter, stability calculations of the Krasnopovstanskaya ravine, drilling and setting up of observational wells on the slopes of the girder.

Laboratory studies of soils were carried out in accordance with the current regulatory documents, in the geotechnical laboratory of the State Enterprise «DniproDIITS», in December 2007, which passed state accreditation (certificate of certification No. HR - 082/2007, validity 18.06.2007 18.06. 2010).

\section{Purpose}

The purpose of this study is to analyze and substantiate the parameters of soil-cement pile retaining structures on the basis of the results of a comparative finite element simulation of the nonlinear stability problem of the landslide-dangerous section of the Krasnopovstansky gully slope, as well as the determination of optimal parameters of soilcement piles according to the results of a study of the mechanics of landslide processes in the territory. $[3,13]$.

\section{Methodology}

Calculation of the stability of landslide-prone slopes was carried out in the program complex «LIRA-SAPR 2016». Geological elements of the soil were assigned the finite element type FE 271276 (volumetric physically nonlinear FEs for simulating one-sided soil work on compression with allowance for displacement). Soil-cement piles are modeled by rod elements of rigidity of circular cross section, diameter $0.6 \mathrm{~m}$. The plot, viewed with one pile in the task has 29389 finite elements with the number of unknowns of 95254. The length of the pile is $6.5 \mathrm{~m}$. [8, 10].

The modulus of deformation of the soil-cement pile was adopted at $68 \mathrm{MPa}$, according to practical research data. 


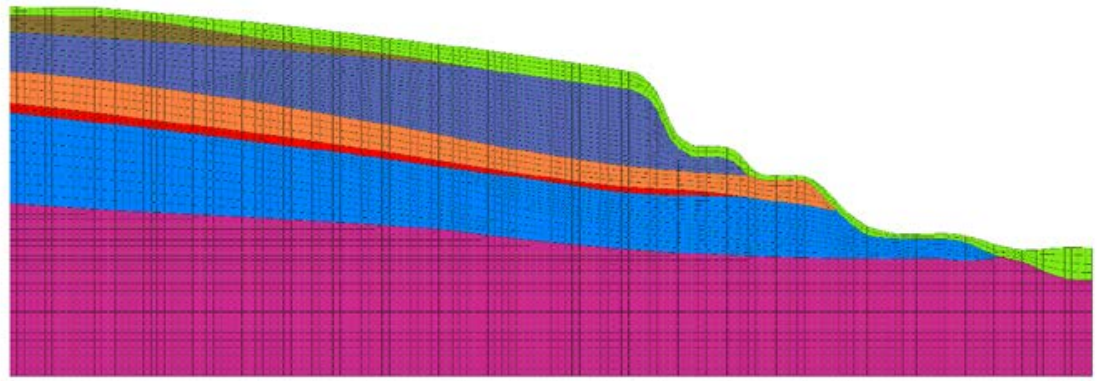

Fig. 1. The finite element model of the landslide slope is considered. The engineering geological layers 1-7 are represented in different colours in order of increasing depth

Calculated values of physical indices and strength of soils at $\alpha=0.95$

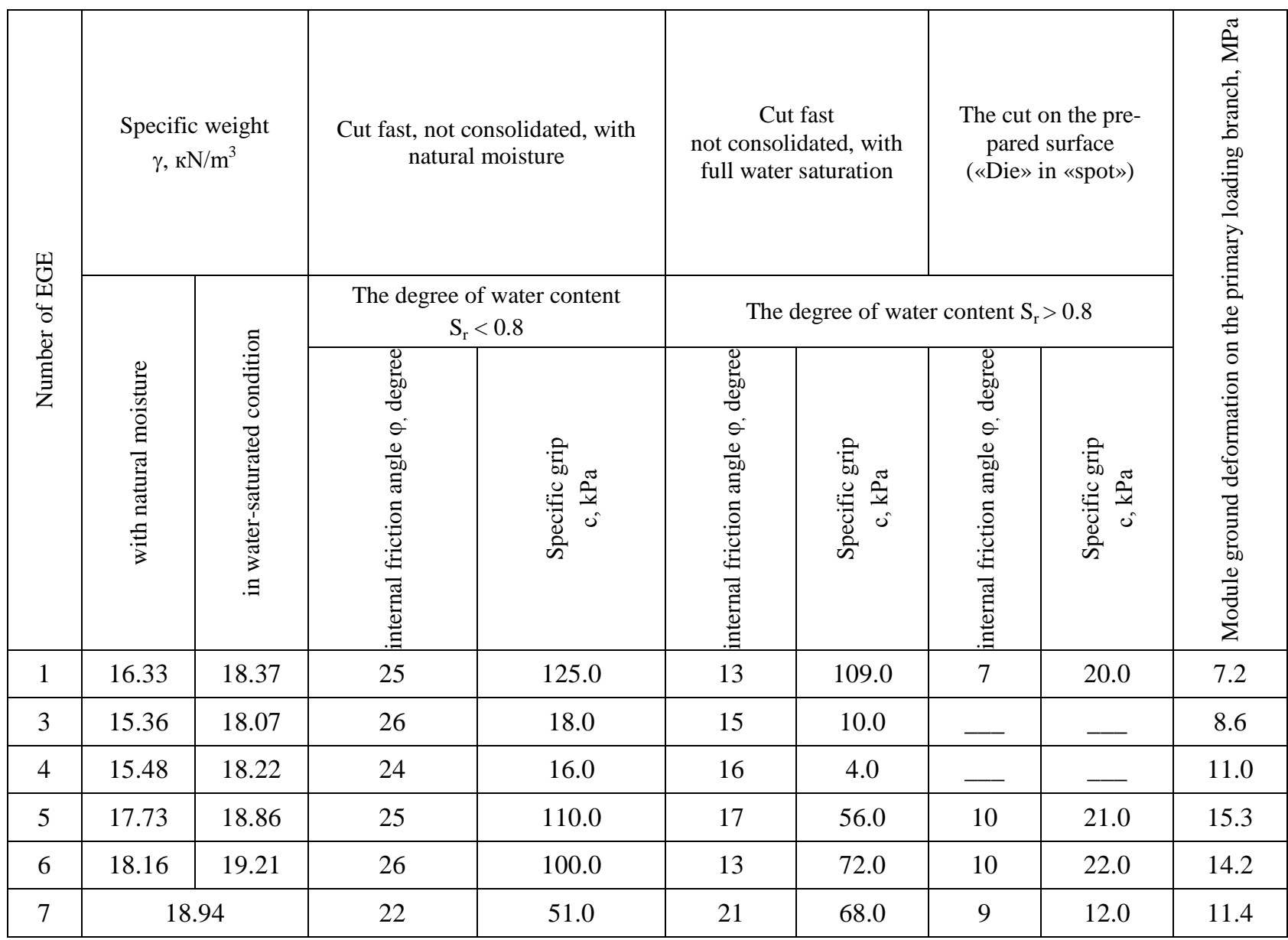




\section{Findings}

The task was calculated in three stages in the «Mounting» processor.

1) The stage «Soil». Reflects the operation of the system without a pile device in conditions where the slope is in a state of equilibrium. Soils are in a state of natural humidity.

2)The stage «Placing piles.» Vertical displace- ments from the sediment of the ground mass are reset. Soils are in a state of natural humidity. The soil-cement pile has been mounted. The pile's own weight acts on the soil mass.

3) The stage «Work piles.» Reflects the work of the pile in conditions of complete water saturation of all soil layers except for the deep one, which is located below the thalweg of the girder.

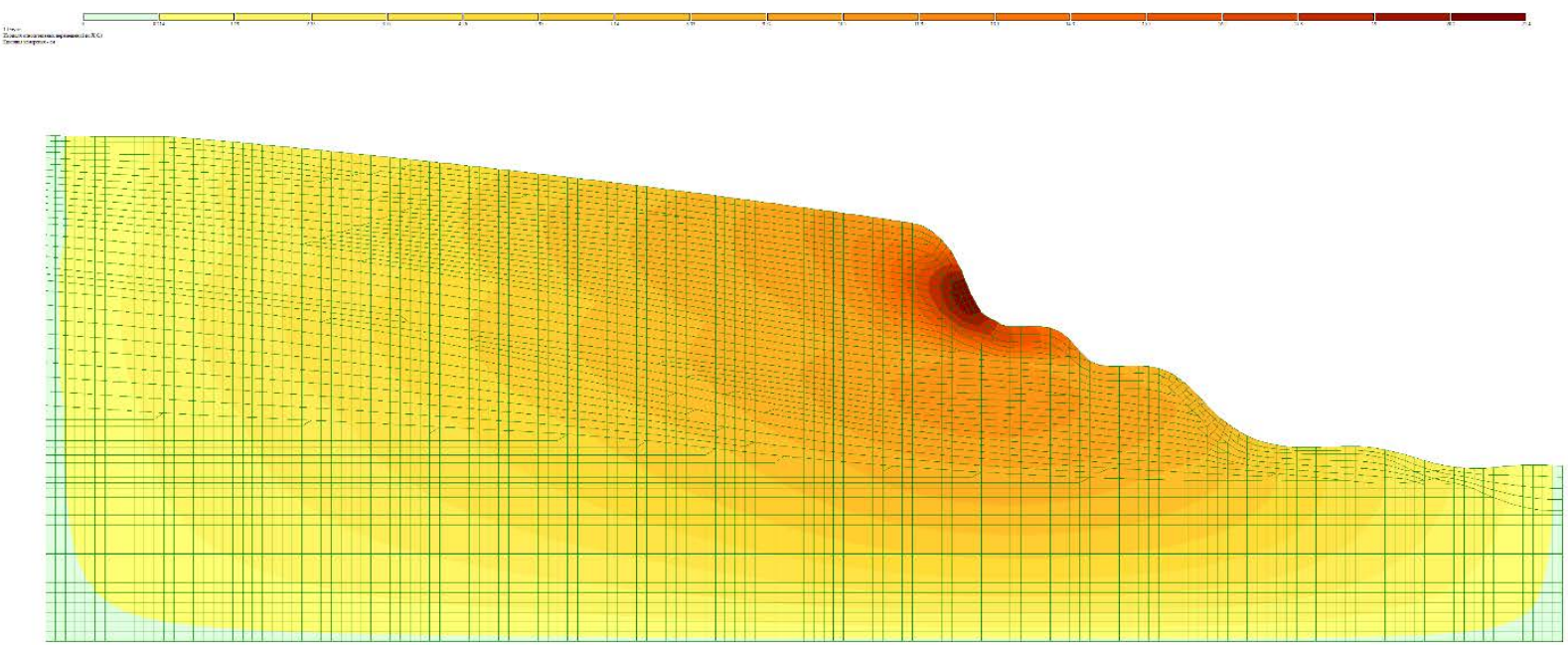

Fig. 2. Stage 1 . The system without placing a retaining structure. The maximum value for the $\mathrm{X}$ axis is $21.4 \mathrm{~cm}$

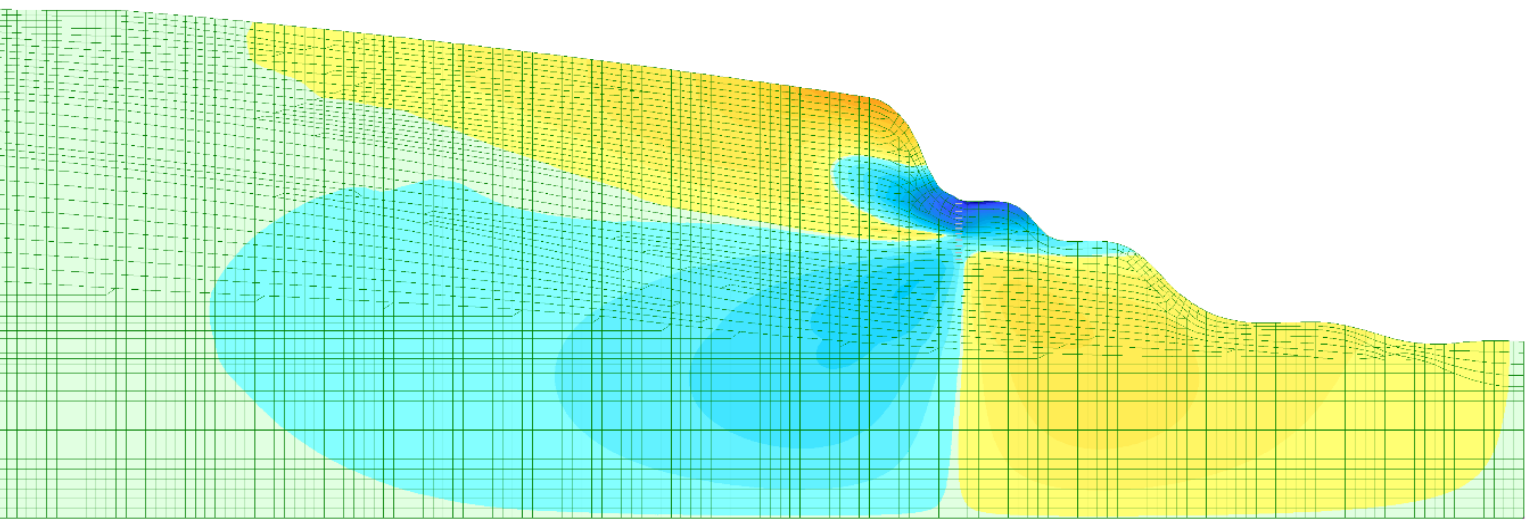

Fig. 3. Moving of the system after the installation of a soil-cement pile with a diameter of $0.6 \mathrm{~m}$, the length of the pile $6.5 \mathrm{~m}$. Soils in the water-saturated state, the situation simulates a possible displacement. The maximum value for the $\mathrm{X}$ axis is $0.025 \mathrm{~cm}$ 


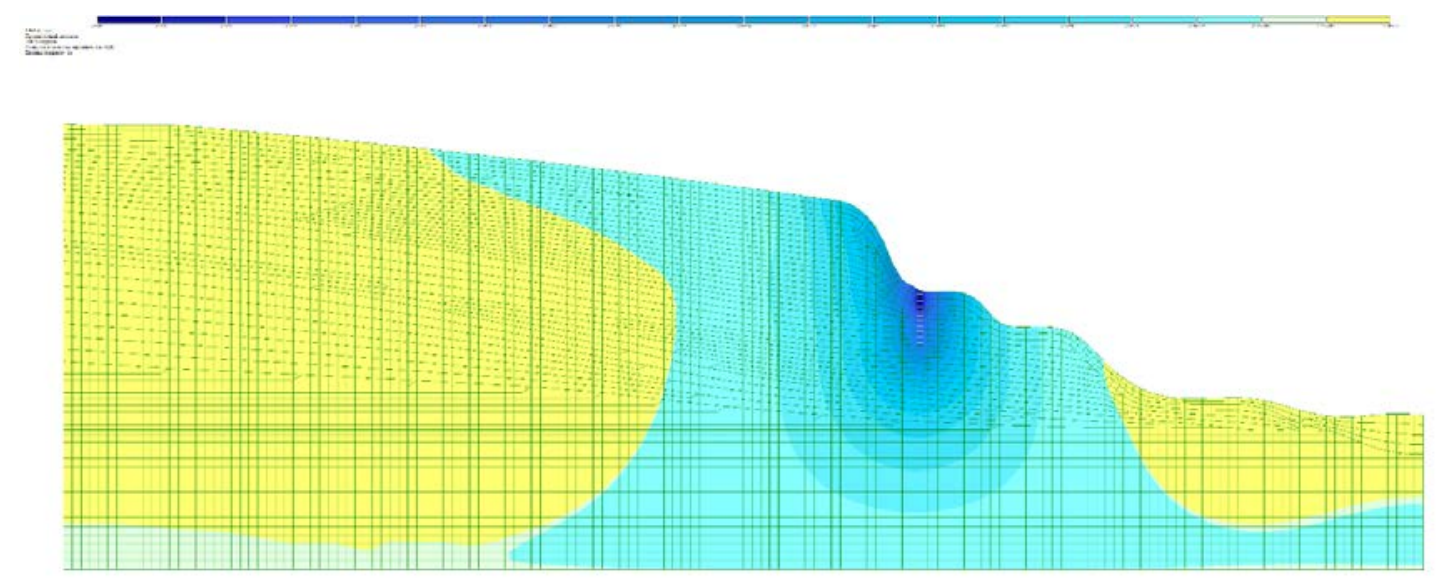

Fig. 3. Vertical displacements of the system after the installation of a soil-cement pile with a diameter of $0.6 \mathrm{~m}$, the length of the pile is $6.5 \mathrm{~m}$. The maximum value along the $\mathrm{Z}$ axis is $-0.14 \mathrm{~cm}$. (Stage 2)

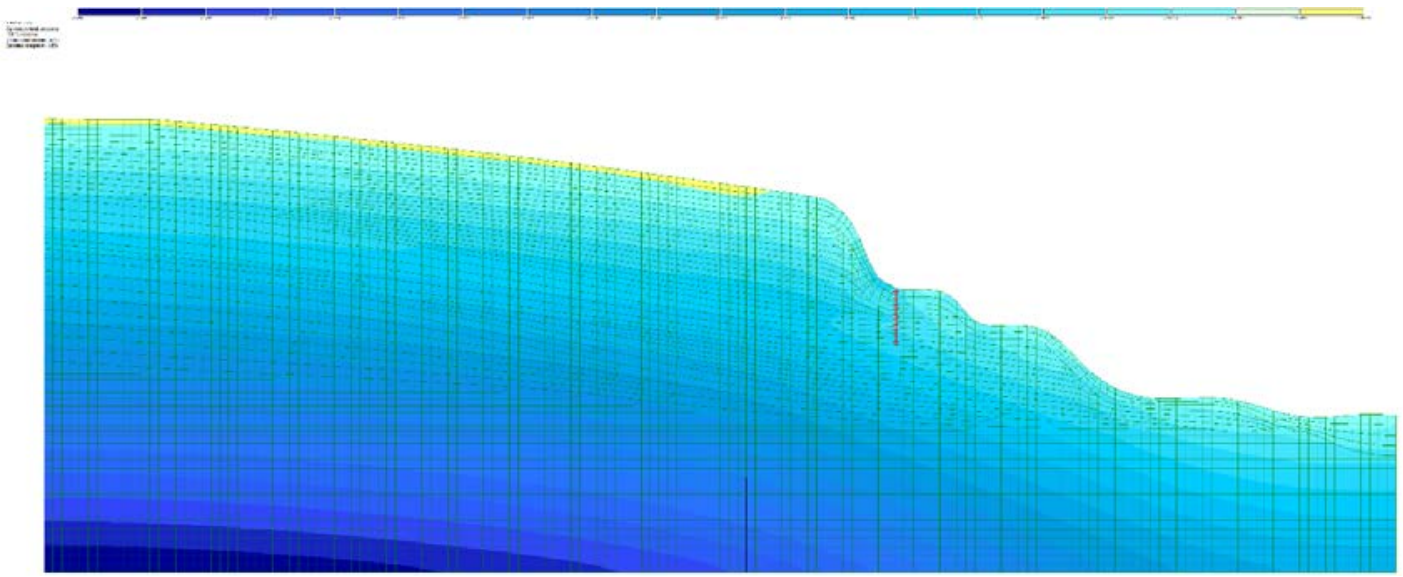

Fig. 4. The isosphere of stresses $\mathrm{N}_{\mathrm{z}}$. The maximum value is $0.494 \mathrm{MPa}$

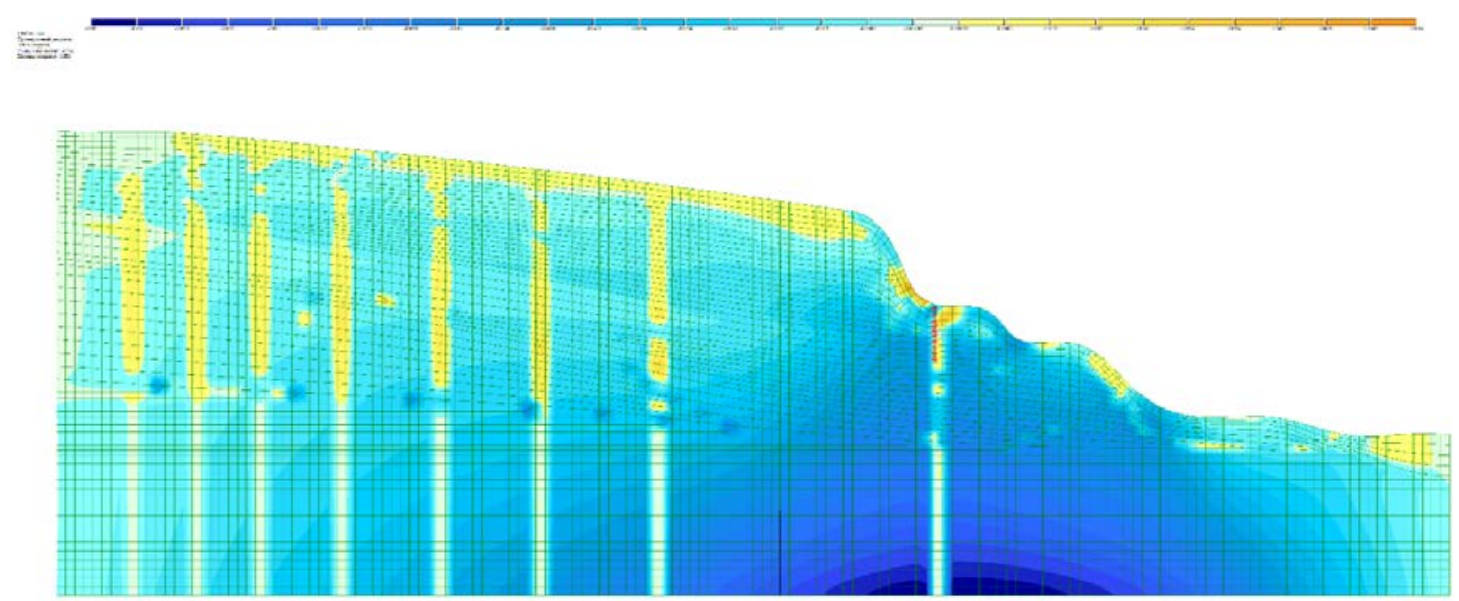

Fig. 5. The isosphere of stresses $\tau_{\mathrm{xy}}$. The maximum value is $0.109 \mathrm{MPa}$ 


\section{Originality and practical value}

Despite the widespread use of soil-cement piles as enclosing structures for the construction of foundation pits and reinforcement of the foundations of emergency structures, special attention should be paid to the study of the feasibility of using soil-cement retaining pile structures on landslide areas. It is known that primer-cement piles are expediently used as a protective element, which interacts quite well with the ground environment due to its structure of the starting material. The use of modern computer programs of finite element modeling makes it possible to calculate the effectiveness of the use of soil-cement piles and to determine the parameters of the necessary supporting structure according to the given geological structure of the slope, and also, depending on its shape and the physical characteristics of the soils, to compare the performance of different types of protective landslide structures.

\section{Conclusions}

Based on the calculations performed, the following findings can be drawn:

1 . The use of soil-cement retaining pile as retaining structures on landslide-prone areas makes it possible to prevent lateral processes if work has been performed based on a preliminary calculation of the nonlinear stability problem. The piles should be arranged in such a way that they can be technologically carried out, that is, the site should be close to the horizontal surface in the terrain for the operation of machinery. The length of the piles should be determined by calculation and taken in such a way that the pile passes the slip surface of a possible displacement and is submerged below, in a stable layer of soil, at least one third of the total length of the pile.

2. The results of the calculated parameters and the bearing capacity of the piles always depend on the given conditions and the initial data of the problem. An error in geological data can lead to erroneous results and a mismatch of the work of the calculation model in reality.

3. The accuracy of calculations of this model for the number of 300 iterations is $10.09 \%$. That is, with a displacement of $0.025 \mathrm{~cm}$, the error of the results is $\pm 0.0025 \mathrm{~mm}$, which is sufficient for this task.

4. With the help of finite element modeling it is possible to solve the practical problem of any complexity, regardless of the variety of geological conditions and the shape of the slope. However, it cannot be to say about other methods of calculating landslide processes in that way.

\section{LIST OF REFRENCE LINKS}

1. Гинзбург, Л. К. Противооползневые сооружения : монография / К. Гинзбург. - Днепропетровск : Лира ЛТД, 2007. - $188 \mathrm{c}$.

2. ДБН В.1.1-24:2009. Інженерний захист територій, будинків і споруд від зсувів та обвалів. Основні положення. - Чинний від 2010-07-01. - Київ : Держстандарт України, 2010. - 69 с.

3. Дорфман, А. Г. Исследование устойчивости склонов / А. Г. Дорфман, А. Я. Туровская // Вопросы геотехники : межвуз. сб. науч. тр. - Днепропетровск, 1975. - № 24. - С. 132-156.

4. Кіріяк, К. К. Обгрунтування технологічних параметрів ін'єкційного закріплення зсувонебезпечних грунтових структур : автореф. дис. ... канд. техн. наук : 05.15.09 / Кіріяк Костянтин Костянтинович ; ДВНЗ «Дніпропетр. нац. гірн. ун-т». - Дніпропетровськ, 2013. - 17 с.

5. Ковров, А. С. Геомеханическое обоснование параметров устойчивых откосов карьеров в сложноструктурном массиве мягких пород : дис. ... канд. техн. наук : 05.15.09 / Ковров Александр Станиславович. Днепропетровск, 2011. - 175 с.

6. Ковров, О. С. Оцінка впливу гідрогеологічних характеристик грунтів на стійкість природних схилів для прогнозу зсувів / О. С. Ковров // Екологічна безпека. - 2013. - Вип. 1. - С. 72-76.

7. Оползни. Исследование и укрепление / под ред. Р. Шустера, Р. Кризека. - Москва : Мир, 1981. - 368 с. 
8. Оцінка стійкості природних схилів методами математичного моделювання в програмі «ОТКОС»/ В. Д. Петренко, О. Л. Тютькін, О. І. Дубінчик, В. Р. Кільдєєв // Мости та тунелі: теорія, дослідження, практика. - 2015. - Вип. 8. - С. 23-32.

9. Строкова, Л. А. Определение параметров для численного моделирования поведения грунтов / Л. А. Строкова // Изв. Томск. политехн. ун-та. - 2008. - Т. 313, № 1. - С. 69-74.

10. Федоровский, В. Г. Метод расчета устойчивости откосов и склонов / В. Г. Федоровский, С. В. Курилло // Геоэкология. - 1997. - № 6. - С. 95-106.

11. Albataineh, N. Slope stability analysis using 2D and 3D methods / N. Albataineh. - Ohio, United States : The university of Akron, 2006. - 126 p.

12. Griffits, D. V. Slope stability analysis by finite elements / D. V.Griffits, P. A. Lane // Geotechnique. - 1999. Vol. 49, No. 3. - P. 387-403. doi: 10.1680/geot.1999.49.3.387.

13. Petrenko, V. D. Estimation of Subgrade Strengthening Influence Using Soilcement Elements / V. D. Petrenko, O. L. Tiutkin, I. O. Sviatko // Наука та прогрес транспорту. - 2016. - № 4 (64). - C. 161168. doi: 10.15802/stp2016/78254.

14. Petrenko, V. D. The application of injection - grouting for strengthening of the weak subgrade foundations / V. D. Petrenko, I. O. Sviatko, D. O. Yampolskyy // Строительство. Материаловедение. Машиностроение. Серия: Инновационные технологии жизненного цикла объектов жилищно-гражданского, промышленного и транспортного назначения : сб. науч. тр. / Приднепров. гос. акад. стр-ва и архитектуры. - Днепропетровск, 2014. - Вып. 77. - С. 144-147.

\author{
Д. Ю. ГГНАТЕНКО ${ }^{1^{*}}$, В. Д. ПЕТРЕНКО ${ }^{2 *}$ А. Л. ТЮТЬКІН ${ }^{3 *}$ \\ ${ }^{1 *}$ Каф. «Мости та тунелі», Дніпропетровський національний університет залізничного транспорту імені академіка \\ В. Лазаряна, вул. Лазаряна, 2, Дніпро, Україна, 49010, тел. +38 (093) 44236 63, ел. пошта dola1992@i.ua, \\ ORCID 0000-0001-6805-6703 \\ ${ }^{2 *}$ Каф. «Мости та тунелі», Дніпропетровський національний університет залізничного транспорту імені академіка \\ В. Лазаряна, вул. Лазаряна, 2, Дніпро, Україна, 49010, тел. +38 (050) 70850 69, ел. пошта petrenko1937@mail.ru, \\ ORCID 0000-0002-5902-6155 \\ ${ }^{3 *}$ Каф. «Мости та тунелі», Дніпропетровський національний університет залізничного транспорту імені академіка \\ В. Лазаряна, вул. Лазаряна, 2, Дніпро, Україна, 49010, тел. +38 (096) 92538 28, ел. пошта tutkin@mail.ru, \\ ORCID 0000-0003-4921-4758
}

\title{
ВЗАСМОДІЯ ГРУНТОЦЕМЕНТНИХ ПАЛЬОВИХ ПІДПІРНИ КОНСТРУКЦІЙ ІЗ ТІЛОМ ЗСУВУ
}

Мета. Наукова робота має за мету аналіз та порівняння результатів розрахунку кінцево-елементної моделі зсувонебезпечного схилу з влаштуванням грунтоцементних паль залежно від зміни жорсткості підпірної конструкції. Дослідження дозволить оцінити ефективність їх застосування, сумісну роботу паль із тілом зсуву та зробити висновок щодо доцільності використання даного методу протизсувного захисту схилу. Методика. Дослідниками проведений аналіз геоморфологічних даних, отриманих за результатами лабораторних досліджень грунтів на ділянці схилу. Створена об'ємна кінцево-елементна модель схилу згідно побудованих розрізів та глибин залягання шарів грунту. Здійснений розрахунок нелінійної задачі кінцевоелементного моделювання схилу 3 влаштуванням грунтоцементних паль різної жорсткості. Результати. Авторами отримані результати розрахунку кінцево-елементної моделі зсувонебезпечного схилу, проведено аналіз напружено-деформованого стану конструкції 3 грунтоцементних паль. Наукова новизна. Незважаючи на широке застосування грунтоцементних паль у якості захисних конструкцій для влаштування котлованів та посилення фундаментів аварійних споруд, особливу увагу слід приділити дослідженню доцільності застосування грунтоцементних підпірних пальових конструкції на зсувонебезпечних ділянках. Практична значимість. Відомо, що грунтоцементні палі доцільно застосовувати як захисний елемент, який досить добре взаємодіє із грунтовим середовищем завдяки своїй структурі вихідного матеріалу. Використання сучасних комп'ютерних програм кінцево-елементного моделювання дозволяє провести 
розрахунок ефективності застосування грунтоцементних паль та визначити параметри необхідної підпірної конструкції згідно даної геологічної структури схилу. Також можливо, залежно від форми та зміни фізичних характеристик грунтів, порівняти роботу різних типів захисних протизсувних конструкцій.

Ключові слова: грунтоцементна паля; зсув; протизсувна підпірна конструкція; зсувонебезпечний схил

\author{
Д. Ю. ИГНАТЕНКО ${ }^{1 *}$, В. Д. ПЕТРЕНКО ${ }^{2 *}$ А. Л. ТЮТЬКИН ${ }^{3 *}$ \\ 1* Каф. «Мосты и тоннели», Днепропетровский национальный университет железнодорожного транспорта имени \\ академика В. Лазаряна, ул. Лазаряна, 2, Днипро, Украина, 49010, тел. +38 (093) 44236 36, эл. почта dola1992@i.ua, \\ ORCID 0000-0001-6805-6703 \\ ${ }^{2 *}$ Каф. «Мосты и тоннели», Днепропетровский национальный университет железнодорожного транспорта имени \\ академика В. Лазаряна, ул. Лазаряна, 2, Днипро, Украина, 49010, тел. +38 (050) 7085069 , \\ эл. почта petrenko1937@mail.ru, ORCID 0000-0002-5902-6155 \\ ${ }^{3 *}$ Каф. «Мосты и тоннели», Днепропетровский национальный университет железнодорожного транспорта имени \\ академика В. Лазаряна, ул. Лазаряна, 2, Днипро, Украина, 49010, тел. +38 (096) 92538 28, эл. почта tutkin@mail.ru, \\ ORCID 0000-0003-4921-4758
}

\title{
ВЗАИМОДЕЙСТВИЕ ГРУНТОЦЕМЕНТНЫХ СВАЙНЫХ ПОДПОРНЫХ КОНСТРУКЦИЙ С ТЕЛОМ ОПОЛЗНЯ
}

Цель. Научная работа своей целью имеет анализ и сравнение результатов расчета конечно-элементной модели оползнеопасного склона с устройством грунтоцементных свай в зависимости от изменения жесткости подпорной конструкции. Исследование позволит оценить эффективность их применения, совместную работу свай с телом оползня и сделать вывод о целесообразности использования данного метода противооползневой защиты склона. Методика. Исследователями был проведен анализ геоморфологических данных, полученных по результатам лабораторных исследований грунта на участке склона. Создана объемная конечно-элементная модель склона согласно построенных разрезов и глубин залегания слоев почвы. Произведен расчет нелинейной задачи конечно-элементного моделирования склона с устройством грунтоцементных свай различной жесткости. Результаты. Авторами получены результаты расчета конечно-элементной модели оползнеопасного склона, проведен анализ напряженно-деформированного состояния конструкции с грунтоцементными сваями. Научная новизна. Несмотря на широкое применение грунтоцементных свай в качестве ограждающих конструкций для устройства котлованов и усиление фундаментов аварийных сооружений, особое внимание следует уделить исследованию целесообразности применения грунтоцементных подпорных свайных конструкций на оползнеопасных участках. Практическая значимость. Известно, что грунтоцементные сваи целесообразно применять как защитный элемент, который достаточно хорошо взаимодействует с грунтовой средой благодаря своей структуре исходного материала. Использование современных компьютерных программ конечно-элементного моделирования позволяет провести расчет эффективности применения грунтоцементных свай и определить параметры необходимой подпорной конструкции согласно данной геологической структуре склона. Также возможно, в зависимости от формы и изменения физических характеристик грунтов, сравнить работу разных типов защитных противооползневых конструкций.

Ключевые слова: грунтоцементная свая; оползень; противооползневая подпорная конструкция; оползнеопасный склон

\section{REFRENCES}

1. Ginzburg, L. K. (2007). Protivoopolznevyye sooruzheniya [Monograph]. Dnepropetrovsk: Lira LTD.

2. Inzhenernyi zakhyst terytorii, budynkiv i sporud vid zsuviv ta obvaliv. Osnovni polozhennia, DBN V.1.124:2009 (2010).

3. Dorfman, A. G., \& Turovskaya, A. Y. (1975). Issledovanie ustoychivosti sklonov. Voprosy geotekhniki, 24, 132-156. 
4. Kiriyak, K. K. (2013). Justification technological parameters of injection landslip stabilization of soil structure. (PhD thesis). Available from National Mining University, Dnipropetrovsk.

5. Kovrov, O. S. (2011). Geomechanical justification of stable open-pit slopes parameters in complex structure massif of soft rocks. (PhD thesis). Available from National Mining University, Dnipropetrovsk.

6. Kovrov, O. S. (2013). Evaluation of the influence of soil hydrogeological properties on stability natural slopes for the forecasting landslides. Ecological Safety, 1, 72-76.

7. Schuster, R., \& Krizek, R. (Eds.). (1981). Landslides. Analysis and Control. (A. A. Varga, R. R. Tizdel, Trans.). Moscow: Mir.

8. Petrenko, V. D., Tiutkin, O. L., Dubinchik, O. I., \& Kildieiev, V. R. (2015). Assess the stability of natural slopes of mathematical modeling in the «Otkos». Bridges and tunnels: Theory, Research, Practice, 8, 23-32.

9. Strokova, L. A. (2008). Opredeleniye parametrov dlya chislennogo modelirovaniya povedeniya gruntov. Bulletin of the Tomsk Polytechnic University, 313 (1), 69-74.

10. Fedorovskiy, V. G., Kurillo, S. V. (1997). Metod rascheta ustoychivosti otkosov i sklonov. Geoekologiya, 6, 95-106.

11. Albataineh, N. (2006). Slope stability analysis using 2D and 3D methods. (MS Thesis). Ohio, United States: The University of Akron. from https://etd.ohiolink.edu/rws_etd/document/get/akron1153719372/inline

12. Griffits, D. V., \& Lane, P. A. (1999). Slope stability analysis by finite elements. Geotechnique, 49 (3), 387403. doi:10.1680/geot.1999.49.3.387

13. Petrenko, V. D., Tiutkin, O. L., \& Sviatko, I. O. (2016). Estimation of Subgrade Strengthening Influence Using Soilcement Elements. Science and Transport Progress, 4 (64), 161-168. doi:10.15802/stp2016/78254

14. Petrenko, V. D., Sviatko, I. O., \& Yampolskyy, D. O. (2014). The application of injection - grouting for strengthening of the weak subgrade foundations. Construction, materials science, mechanical engineering. Series: Innovative lifecycle technology of housing and civil, industrial and transportation purposes, 77, 144-147.

Prof. M. B. Kurhan, Dr. Sc. (Ukraine); Prof. S. M. Hapieiev, D. Sc. (Tech.), (Ukraine) recommended this article to be published

Accessed: May 11, 2017

Received: Sep. 28, 2017 